9. Lypa, Yu. (1937). Gadyuchky: Novela [Vipers: novella]. Notatny`k 3: Novely. L`viv: Xortycya, 159-162.

10. Materiyaly do istoriyi literatury i gromads koyi dumky. T. 3: Lystuvannya z amerykans`kyx arxiviv [Materials on the history of literature and public opinion. Volume 3: Correspondence from the American Archives]. 1857-1933 / UVAN u SShA; Red.: B. Strumins`kyj, M. Skorups`ka u spivpraci z E. Kasyncem i N. Livycz`koyu-Xolodnoyu; Vstup. st.: M. Rayev, M. Skorups`ka; Zag. red.: Ya. Bilins`kyj, V. Omel`chenko, O. Fedyshyn. N`yu-Jork, 1992. 527-751.

11. Narizhna, N. (2010). Dytyachymy ochyma. (Spomyn) [Baby eyes. Memory]. Praga: Vydalo Sdruženi v České Republice.

12. Pelens`ka O. Ukrayinci v Chexoslovachchy`nitarezhymStalina. Represiyi 1945 r. [Ukrainians in Czechoslovakia and the Stalin regime. Reprisals of 1945]. URL: https://www.radiosvoboda.org/a/29245913.html (data zvernennya: 25.05.2018).

13. Ponomar’ov, V. Dmytro Chyzhevs`kyj: filosof, shho lyubyv kotiv [Dmytro Chizhevsky: a philosopher who loved cats]. URL: http://politikan.com.ua/8/6/0/ 49096.htm (data zvernennya: 25.05.2015).

14. Pushkareva, N. Istorija povsednevnosti, kak napravlenie «istoricheskih issledovanij» [The history of everyday life as a direction of "historical research»]. URL: http://www.perspektivy.info/print.php?ID=50280 (data zvernennya: 1.06.2016).

15. Simyanciv, V. (1978). Inzhener-emigrant u Chexo-Slovachchyni [Emigrant engineer in Czech Republic]. Buenos-Ajres-Filadel fiya: V-vo Yuliyana Seredyaka.

УДК 94(4).396

\title{
НАРОДНЕ ВБРАННЯ КАРПАТСЬКОЇ УКРАЇНИ ЯК ВІДОБРАЖЕННЯ ЕТНІЧНОЇ СПІЛЬНОСТІ ЄВРОПЕЙСЬКИХ НАРОДІВ
}

\section{Мартинчук Інна}

У статті розглянутий вплив регіонального фактора на формування традииійного костюма як культурної иіннісної спільності етнічної історії європейських народів. Аналіз досліджень наукового доробку окресленої проблеми, зокрема робіт О. Косміної, К. Матейко, Т. Ніколаєвої, Т. Кара-Васильєвої, Г. Стельмашука, В. Коиана, С. Кривопустової та інших фахівців, дали можливість визначити і узагальнити етнічні взаємовпливи європейських народів, процеси міжкультурної комунікації на формування народного костюма.

Головна увага зосереджена на виявленні самобутніх рис та етнічних запозичень у процесі формування і розвитку народного одягу етнографічних груп українців Закарпаття. У ході дослідження було з'ясовано, щуо схожість традиційного вбрання українців з сусідніми етнічними групами обумовлюється спільними кліматичними умовами, географічним розмі- 
щенням, рельєфом місиевості та історичними особливостями розвитку. Наявність значної кількості спільних різновидів елементів одягу, орнаментальних мотивів і прийомів його оздоблення стало спільним елементом розвитку традиційної культури етнічного порубіжжя. Етноісторичний та господарський розвиток украӥнців Закарпаття позначився, насамперед, на локальних особливостях одягового комплексу, зокрема на способах компонування, колориті, технічних прийомах у вишивиі, орнаментальних мотивах. Аналіз мотивів орнаментики, композиційних прийомів, розташування декору, функиіональне призначення елементів народного костюма тісно пов'язані та взаємообумовлені, щцо дозволило з'ясувати ті основні фактори, які безпосередньо пов'язані з місиевими особливостями народного строю украйнців Закарnammя.

Ключові слова: Карпатська Україна, етнічне порубіжжя, етнографічна група, традиизійна культура, народне вбрання.

Формування українського традиційного костюма залежало від звичаїв та вірувань, міжетнічних зв'язків, які відбивали світогляд людини, суспільства. Костюм демонстрував ставлення людей до різних зовнішніх факторів, підкреслював їхній віковий, статевий, соціальний стан. Окрім того, у традиційному костюмі втілювалися художньо-естетичні погляди та етичні норми суспільного життя. Виходячи 3 цього, вивчення традиційного вбрання етнічного порубіжжя, визначення спільних різновидів і орнаментальних мотивів вважаємо актуальним і необхідним для збереження народних традицій, що найдовше зберігаються в одязі того чи іншого етносу і є продуктом багатовікового колективного досвіду народу. Вважаємо, що дослідження елементів повсякденної культури допомагає у вивченні та розумінні досягнень духовної культури народу.

У сучасному науковому просторі з'являється все більше досліджень, які спрямовані на вивчення генези народного костюма, його місця в етнічній культурі, у формуванні світосприйняття українців. Більшість досліджень у сфері вивчення народного костюма базується на основі архівних, етнографічних і літературних джерел.

Найбільш повно результати наукових розвідок народного українського костюма, на наш погляд, містяться у монографії Т. Ніколаєвої «Історія українського костюма» і статті В. Коцана «Традиційний народний одяг як прояв ідентичності етнографічних груп українців Закарпаття (XIX - першої половини ХХ ст.)» $[12 ; 8]$. Автори звертають увагу на регіональні, гендерні та вікові аспекти формування традиційного одягу. Важливим доповненням до теоретичного матеріалу є значна кількість зображень деталей костюма повсякденного та святкового вжитку.

Зображення українського костюма також представлені у роботах О. Косміної «Традиційне вбрання українців» [6], М. Білана, Г. Стельмащук «Український стрій» [1], 3. Васіна «Український літопис вбрання» [2] та інших. Вони відбивають історію формування комплексу українського традиційного одягу та містять описи його окремих деталей. 
Окрім досліджень, що містять загальну характеристику народного вбрання українців, доцільно назвати спеціальні дослідження, автори яких відтворюють особливості окремих деталей, їхнє змістовне навантаження. Для нашого дослідження цікавими були й дослідження регіонального характеру, які аналізують риси, притаманні традиційному костюму певного історико-етнографічного регіону. Насамперед, це дослідження В. Коцана «Традиційний народний одяг гуцулів Рахівщини: XIX - перша половина XX ст.» [7], К. Матейко, О. Полянської «Одяг. Гуцульщина: історико-етнографічне дослідження» [10], В. Зеленчука «Костюм румынского населения Закарпатской области УССР» [4].

Аналіз літератури дозволив 3'ясувати необхідність проведення дослідження проблеми спільності етнічних культурних традицій європейських народів на прикладі народного вбрання українського населення Закарпаття та сусідніх етносів. Метою дослідження $\epsilon$ визначення на основі порівняльного аналізу комплексів традиційного вбрання, ступеня культурних взаємовпливів на формування народного одягу етнографічних груп українців Закарпаття. Стаття спирається на матеріали етнографічних розвідок «Етнографічний образ сучасної України. Корпус експедиційних фольклорно-етнографічних досліджень» [3].

Треба відзначити, що схожість традиційного вбрання українців з сусідніми етнічними групами обумовлюється спільними кліматичними умовами, географічним розміщенням, рельєфом місцевості, торговими зв'язками та історичними особливостями розвитку.

При описі комплекту жіночого народного вбрання гуцулок Закарпаття дослідники традиційно виділяють сорочку, двоплатові пілки («запаски»), пояс («окрайка»), безрукавку («кептар»), сукняну куртку («сердак»), кожух, головні убори, прикраси та взуття $[9,87]$. Характерним плечовим одягом гуцулів був «кептар» - безрукавка на хутрі, оздоблена вишивкою та аплікацією. Жіночі кептарі оздоблювались смугами лисячого хутра, каракулем чи смушком, шкіряними аплікаціями, бляшками, китицями та багатобарвною вишивкою, яка не заповнювала всього тла, а ось румунські безрукавки («кожки») оздоблювали суцільною вишивкою червоно-бордовими нитками, шкіряними аплікаціями і китицями $[8,60]$. Тому гуцулку в «кептарі» легко було відрізнити від румунки в «кожну». Хутряні безрукавки («бунди») долинянок майже нічим не відрізнялись від румунських.

Детальна характеристика традиційного жіночого вбрання бойків Закарпаття надається в роботі М. Білана, Г. Стельмащука «Український стрій». На думку авторів, комплект складався з короткої сорочки («опліччя»), спідниці, фартуха, безрукавки, гуні чи кожуха, куртки, головних уборів та взуття. У другій половині XIX - в першій половині XX ст. основу традиційного жіночого вбрання бойків Закарпаття складала коротка сорочка («опліччя») 3 домотканого полотна, 3 
круглим вирізом горловини, скісним розрізом пазухи з правого чи лівого боку, густо зібраною нагрудною частиною, довгими рукавами 3 пришивними манжетами $[1,15]$. Відмінності полягали у формах та розмірах окремих орнаментальних композицій, їхньому розміщенні на сорочці, внутрішньому оздобленні та орнаментальному навантаженні.

Порівнюючи традиційний костюм Румунії і Буковини, схожими можна назвати лише жіночі головні убори. Румунки використовували фес (феску) червоного або білого кольору, і на Буковині жінки використовували червоний фес, який у деяких місцевостях прикрашали стрічкою з монетою («ліліче ді мердзяле»). Вважається, що фес розповсюдився на цих територіях завдяки турецькому пануванню на Балканах. Звичними для румунок є рушниковий вид головного убору («марама», «тулпан»), який притаманний й жіночому традиційному костюму України у вигляді намітки, а більш удосконаленою була хустка.

Схожими були елементи оздоблення одягу Румунії і Буковини: румунці використовували бісер для прикрашання жіночих сорочок, а українки Буковини оздоблювали бісером «коду» - головний убір з картону, обшитий тканиною [11]. Як і на Буковині румунці носили шкіряне взуття («церухе»), але воно відрізнялося манерою шиття, кольором, оздобленням.

При порівнянні закарпатського і румунського традиційних костюмів зупинимось на найпоширенішому елементі одягу - сорочці. Як у Румунії, так і в українському Закарпатті був поширений вид сорочки, що призбирався біля горловини. Святкові й буденні сорочки Румунії і Закарпаття шили з конопляного полотна. Кроїли їх «до уставки» із 3-5 полотнищ. Верх збирали на міцну нитку й викінчували обшивкою, яка відрізнялася у румун і українців Закарпаття. Цей варіант сорочки, який ще називають карпатським, зберігся також у північній Молдові. Протягом століть чоловіча і жіноча сорочки румунів Закарпаття зазнали незначних змін, залишаючись символом-знаком, демонструючи етнографічну й етнонаціональну приналежність.

На думку дослідниці А. Іваниш, вплив румунської сорочки виражається у безлічі типологічно-декоративних варіацій, позначених архаїчними способами крою та різновидами прийомів орнаментального оздоблення, які тісно пов'язані 3 обереговим, статево-віковим, естетичним, етнорозпізнавальним та іншим призначенням. Авторка вважає, що румунський вплив у структурі народної сорочки прослідковується за конструктивним вирішенням і способом виготовлення, з'єднання полотнищ рукавів на сорочці (від плеча або від шиї). Існують два основні типи сорочок у румунському жіночому народному одязі: тунікоподібна сорочка та сорочка, призбирана біля шиї «морщенка», такі види сорочок співіснували поряд в усьому румунському просторі [5, 309-310]. 
Отже, ми дійшли висновку, що фантазія угорських і румунських селян створювала унікальні вироби, які були поширені в середовищі і бідного, і багатого населення Закарпаття першої половини XX ст. Принципи створення угорських шкіряних бунд виникали поступово, відбувався розвиток і трансформація з однієї форми до іншої залежно від регіональних смаків, традицій та тенденцій тодішньої моди. Художня цінність такого традиційного одягу полягає в тому, що майстер кушнірства віртуозно застосовував найскладніші елементи крою, структури та оздоблення.

Зіставляючи традиційний костюм Угорщини і Закарпаття, звернемо увагу на схожість розміщення рясної вишивки на рукавах шаркезьких, калотасегських i тороцкойських жіночих сорочках на один з видів сорочки жінок Закарпаття «вузька уставка», в якій вишивка традиційно розміщується вгорі рукавів. Сорочки чоловіків західної частини Закарпаття були короткими, як і в угорців півночі і заходу країни.

Для карпатських українців загалом характерні вузькі штани - «гачі», але традиційними для чоловіків Західного Закарпаття є широкі штани, такі ж, як і у народному костюмі чоловіків східної Угорщини. Цікаво, що для західних угорських етнічних земель характерні вузькі штани, як і для карпатських українців загалом. Для пошиття «сюра» північно-східної Угорщини і закарпатської «гуні» використовували біле сукно. Обидва виготовлялись пращоподібної форми. Як і в українців, серед угорського традиційного зимового вбрання була хутряна накидка («шуба»).

Поясний одяг як в українців, так і в угорців виготовлявся зі шкіри, різниця була тільки в ширині. Жінки Західного Закарпаття, так само як і в угорському народному костюмі, використовували стеклярус (бісер) для оздоблення головних уборів $[13,68]$.

Схожість у взутті угорців і українців західного Закарпаття полягала у тому, що однаково обгортали ногу шматком полотна, перед тим як вдягти «постіл» (у випадку українців), або лаптів, які носили угорці. У західному Закарпатті традиційним взуттям були постоли, які виготовляли зі шкіри, як і взуття Алфельду (рівнина, що займає південну та східну частину Угорщини, східної Словаччини, південно-західну Україну, західну Румунію) [13, 70].

Таким чином, поширені різновиди одягових комплексів, які вирізняються конструктивними відмінностями та особливостями народного строю румун та угорців, визначають локалізацію, модифікуючи та впливаючи, формують народний Закарпатський костюм першої половини XX ст. в цілому. Проте очевидно, що ми будемо мати ширший діапазон різновидів, типів одягових варіацій та їхнього оздоблення, коли розглянемо не тільки народний стрій, а й інші побутові 
предмети румунів та угорців Закарпаття. Важливим кроком є дослідження художньо-образної специфіки традиційного народного вбрання та одягових комплексів румунського та угорського населення українських Карпат, що згодом дадуть можливість сформувати загальне уявлення про мистецтво українського народного одягу та дозволять більш грунтовне вивчення взаємовпливів, розвитку народного костюма румунів та угорців Закарпаття.

Внаслідок існування на спільній території з іншими етносами неминучим було переймання частки зовнішніх ознак, хоча вона була не така велика, як схильні визначати польські та словацькі дослідники. Зіставлення ознак лемківського і польського чи словацького вбрання дає лише відомості про його зовнішні відмінності, дуже важко простежити їхні глибинні причини та закономірності.

Натільним одягом як чоловіків, так і жінок на території Лемківщини виступає сорочка. На Лемківщині вона відома під назвами «опліч», «чахлик», «кошуля». Давні лемківські сорочки були безуставкового типу, пізніше почали з'являтися уставкові. На Лемківщині розрізняли верхню і нижню, спідню, сорочку, яка називалася «дріка», «тіснота», «подолок», «опліч», «станок». У неї був простий крій: повздовжню тканину згинали, посередині робили овальний шийний отвір, а з боку пришивали вузькі рукави. Комір висотою 2 см був «зарублений» тонким білим полотном. Оздоблювали сорочки геометричним малюнком червоного і чорного кольору, пізніше - синього, зеленого, жовтого, оранжевого, фіолетового. У другій половині XIX ст. із давньої довгої сорочки поступово виникли два новіші види одягу. Це вузька нижня спідниця («подолок», «подольча», «спідник», «сподник») i коротка сорочка, яка на Словаччині називається «oplecko» чи «rukavce» $[2,205]$.

У районах, сусідніх із Бойківщиною, сорочки були короткими, до поясу («по пупець»), з вузенькою вишивкою на уставці («напліччі», «запліччі»). У східних регіонах, особливо на Великоберезнянщині, - розріз сорочки був не спереду, як в інших частинах Лемківщини, а на спині чи збоку, як робили бойки $[2,428]$. Там побутувала в основному різнокольорова рослинна вишивка гладдю, яку розміщували в центральній частині станка, на верхній плечовій частині рукавів та манжетах по довгих складках.

Короткі рукави у західних та центрально-південних районах з'явилися під впливом словаків. Крім того, словацькі традиції проглядалися у накрохмалюванні та у прийомах викінчення коротких рукавів, а також в обрамленні шийного отвору широкими призбираними («стібаними») виложистими комірами («коміриками») або накрохмаленими воланами («кризами») $[1,91]$.

У західній частині Лемківщини морщення робили біля шиї та на рукавах білою ажурною вишивкою. У північно-західній території, під впливом Польщі та 
Словаччини, на комір та манжети нашивали широкі ткані на кроснах червоні полоси, оздоблені тоненькими білими пасочками, а викінчували манжети білим або червоним мереживом.

Лемківською особливістю було призбирування («рясування») та густе «морщення» станка і верхньої частини рукавів сорочки. На кінці рукава також виконували морщинку, обшивали іiі кольоровими нитками (найчастіше - червоними), залишаючи вільним край, який утворював шлярку.

Переважав усюди рослинний орнамент. Кольори на вишивці варіювались залежно від території побутування: на кордоні з бойками переважали червоні й сині кольори, на межі зі Словаччиною - багатоколірна вишивка, а на землях, що межували 3 польськими групами, було поширене вишивання білими нитками. Чоловічі сорочки давнього типу були короткими, з вузьким шийним отвором, рукави в них були без манжетів, спереду зв'язувалися на застібку. У декількох селах центральної Лемківщини були поширені сорочки з розрізом на плечах, як у бойків Закарпаття, які зв'язувалися довгою стрічкою $[2,246]$. Для такої сорочки характерне вишивання геометричного орнаменту одним кольором - чорним, білим, вишневим, тільки для підкреслення мотивів вживали жовтий чи зелений кольори.

На словацькій стороні крій сорочки був майже такий самий. Шийний отвір зарублювали або пришивали коротенький комірець. На святкових сорочках комірець і краї розрізу вишивали. Пізніше кінці рукавів почали призбирувати у вузьку облямівку, яку застібали на гудзик. На всій території Лемківщини сорочки заправляли в штани.

Найбільш традиційний костюм побутує в південних і східних областях Словаччини. Порівнюючи традиційний одяг Словаччини і Західного Закарпаття, спостерігаємо, що традиційна сорочка словаків тунікоподібного крою, як і в українців західного Закарпаття. У центральній частині Словаччини розповсюджена коротка чоловіча сорочка - така жє традиційною для чоловічого костюма західного Закарпаття. Штани («гаті») словаків і чоловіків західного Закарпаття однакового широкого покрою. Як і українці, словаки прикрашали шкіряні пояси металевими накладками. Гуню Закарпаття, як і галену словаків, шили з білого сукна - верхній одяг пращоподібної форми. Овчинні шуби є притаманними традиційному костюму словаків і українців.

Один із видів жіночої сорочки словаків («рукавце») схожий за покроєм 3 жіночою сорочкою Закарпаття - складається з чотирьох полотнищ, які плісируються зі сторони, яку потім пришивають до кайми, що, у свою чергу, утворює комір. Рукава словацької традиційної сорочки рясно вишиті від ліктя до уставки, що нагадує «заспульницю» - один з видів прикрашання жіночої сорочки Закарпаття. 
Словацьке традиційне чоловіче взуття «карце» схоже на українські гостроносі постоли - так само виготовлялися з продовгуватого шматка шкіри і обв'язувалися навколо ноги шкіряним ремінцем або «волоками» [14, 196-199].

Багато спільного знаходимо у головних уборах жінок Закарпаття і Словаччини. Обидва традиційні ансамблі складаються з обруча (у словаків - «парта»), вінка $з$ квітами і кольорових стрічок, очіпків (чепець), хусток. Словацькі жінки дотримувалися однакових звичаїв з українськими стосовно носіння головних уборів. Вийшовши заміж, словацька жінка мусила обов'язково покривати голову, замінюючи вінки й обручі чепцями. За українськими традиціями, вдома жінки носили прості за виконанням чепці, а на свята вдягали гарно оздоблені, з дорогих тканин, $з$ кольоровими стрічками - ідентичних норм дотримувалися й жінки Словаччини [3, 151-180].

3 точки зору основних видів одягу та взуття в Словаччині в рамках розвитку протягом останніх двох століть вони сформувалися у дві характерні ціліодяг і взуття низинного регіону та одяг і взуття гірського регіону. Не існує різкої межі між двома, але широкий спектр перехідних форм. У центральноєвропейських відносинах комплекс низовинних регіонів поєднує Словаччину з одягом південно-східної Моравії, Східної Австрії, Угорщини, північної Югославії та західної Румунії. Комплекс альпійських районів поєднує Словаччину з південною Польщею, Західною Україною і північною і західною Румунією.

Порівняння традиційних костюмів Лемківщини і Польщі підтверджують попередні висновки щодо спільності умов і шляхів їхнього формування. У лемків вишивка виконується геометричним орнаментом, як і в традиційному костюмі поляків Кшановського району (Люблінський регіон). Також лемки з кшенськими поляками, як і з білгорайськими поляками (Люблінський регіон), однаково використовували «застібки» на комірі - зав'язували гарасівкою (червоною вовняною стрічкою). Як лемкині, так і польські жінки декорували спідниці кольоровими стрічками.

Сондетські і польські жінки (територія півдня Малої Польщі) вплітали червоні стрічки в коси (або в одну) і носили червоні коралі (як і польські білгорайські жінки) - такі ж елементи властиві й традиційному костюму лемків. У складі традиційного костюма сондетських поляків, гірських поляків м. Подхале (Татри) та поляків краківських присутні квітчасті (зелені, сині й червоні) спідниці такі самі носили старі (червоного кольору) і молоді (зеленого й синього кольору) жінки, відколи почали використовувати фабричні тканини. Для оздоблення верхнього одягу сондетські поляки використовували мідні гудзики, якими користувались і лемки для прикрашання лейбика (безрукавки). 
Краківський народний костюм включає вінки («обідок»), як і в лемківському традиційному костюмі, але це більш святковий і весільний елемент, як в Україні й Польщі. Краківські польки зазвичай ходити з непокритою головою.

Схожим у традиційному одязі Сокальщини і пущчацьких поляків (Мазовецька територія) було використання чорної тканини для пошиву жіночих безрукавок («корсет» у поляків, «камізелька» в українців Сокальщини), приталеного крою, підшивали краї полотном контрастного кольору (тасьмою). Однаковим елементом традиційного костюма жінок Сокальщини і полячок м. Ловича були намиста 3 коралів, носили переважно справжні, але й імітацію також використовували [9].

Схожість кшанівського (люблінського) традиційного костюма з вбранням Сокальщини можна помітити у використані «гарасівки» (червоної вовняної стрічки) для зав'язування коміра, а пізніше як полячки, так і українки Сокальщини почали використовувати гудзики. Загалом оксамит, з якого поляки виробляли корсети, українки Сокальщини використовували лише для оздоблення спідниць, верхнього одягу (наприклад, кацабайка).

Традиційне вбрання ополянок (територія Верхньої Сілезії) було схожим на вбрання жінок Сокальщини у манері заплітати волосся у дві коси й укладати його довкола голови «корзинкою». Як і полячки Верхньої Сілезії (також і ловічанки), українки Сокальщини полюбляли носити так звані турецькі хустки - хустки зі східним орнаментом, які прийшли до Європи у XVII ст. $з$ британськими переселенцями і розповсюдилися завдяки торгівельним зв'язкам.

Фартухи ополянок і українок Сокальщини були схожі за оздобленням - використовували мереживо, тасьму. Запаски (фартухи) жінок Сокальщини були вишивані, а ополянки імітували вишивку, оздоблюючи фартухи тасьмою з квітковим орнаментом [9].

Білгорайський традиційний костюм схожий на костюм Сокальщини своїм використанням у вишивці чорних і червоних кольорів. У певний час (до того, як 3'явилися фабричні матеріали) на Сокальщині вважалося звичним носити смугасті спідниці, які донині є традиційним елементом білгорайського костюма. Для зав'язування коміра білгорайки, як і сокальщиці, використовували червону вовняну стрічку (гарасівку).

У дівчат цих регіонів дуже схожа манера укладання волосся, а саме - розділення його посередині і плетіння двох кіс, які укладали довкола голови. Для прикрашання однаково використовували живі або штучні квіти у стрічку.

Порівнюючи стрій Яворівщини і традиційного одягу Польщі, бачимо, що спільним елементом традиційного костюма для поляків м. Подхале (Татри), краківських, сондетських (Мала Польща), кшчонівських, білогорайських поляків та 
українців Яворівщини були коралі. Кшчонівські полячки на однаковий манер з українками Яворівщини традиційно заплітали дві коси, які зав'язували червоною стрічкою. Як і сондетські полячки Малої Польщі, на Яворівщині жінки оздоблювали фартухи мереживом. Шнуровані черевики $є$ елементом як краківського, так і яворівщинського традиційного костюма.

Зіставляючи костюм Галичини і Польщі, помітно, що у складі традиційного львівського костюма є смугасті спідниці, схожу тканину використовували білгорайські полячки. У білгорайських полячок традиційними були українські постоли 3 онучами (у поляків - сабо), які традиційно носили й львівські українки. Традиційними для гірських поляків були вовняні безрукавки, такі притаманні львівському традиційному костюму жінок. В Галичині була надзвичайно поширена силянка (гердан), яка, ймовірно, прийшла до Галичини з Угорщини.

Схожість елементів верхнього традиційного одягу також обумовлюється сусідством регіонів. Верхній традиційний одяг угорців, а саме «сюр», який був розповсюджений на північному сході Угорщини, був схожий на лемківську «чугу». Чуга, як і угорський сюр, схожа на плащ 3 довгими рукавами, зашитими внизу, які використовувалися як кишені. У кшонівському костюмі (Люблінський регіон) вишивку на сорочці виконували білими нитками (коли ще шили сорочки 3 домотканого полотна) так само, як на чоловічих сорочках українців Закарпаття.

Порівнюючи традиційний стрій Волині і Польщі, спостерігаємо, що у традиціях полячок Верхньої Сілезії і дівчат Волині була схожою манера заплітання двох кіс у «корзиночки» довкола голови. Як і білгорайські полячки, українки Волині традиційно вишивали сорочки тільки чорними і червоними нитками. Biзуально схожими були й традиційні спідниці волинянок і кшановських полячок (Люблінський регіон) - кольорові смужки, і по низу спідниці обшивали смугою оксамиту. Хоча пошиття їх різнилося - українки використовували готову смугасту тканину, а люблінські полячки нашивали кольорові стрічки на спідницю. У традиційному костюмі волинянок, на відміну від інших видів західноукраїнського строю, була присутня приталена безрукавка - корсет, який є невід'ємним елементом й польських традиційних костюмів. Шився лише чорного кольору, застібався гудзиками, як у північно-східних полячок Мазовії. Зустрічаються варіанти зі шнуруванням, як у полячок м. Подхале (Татри).

Етноісторичний та господарський розвиток українців Закарпаття позначився, насамперед, на локальних особливостях одягового комплексу, зокрема на способах компонування, колориті, технічних прийомах у вишивці, орнаментальних мотивах. Аналіз мотивів орнаментики, композиційних прийомів, розташування декору, функціональне призначення елементів народного костюма тісно пов'язані та взаємообумовлені, що дозволило з'ясувати ті основні фактори, які безпо- 
середньо пов'язані з місцевими особливостями народного строю українців Закарпаття, на який здебільшого мали вплив угорці. Однак й в угорському костюмі відчутні традиційні самобутні риси, характерні в структурі та будові народному строю етнічних українців.

Художньо-стильовий вплив і еволюція закарпатського костюма на початку $\mathrm{XX}$ ст. вже менш пов'язані з інонаціональним запозиченням. Це, головним чином, топографія декору з його конструктивними особливостями, характером $\mathrm{i}$ фактурністю, що яскраво проявилося в оздобленні традиційного костюма та $\epsilon$ сталим аспектом етнічних ознак угорців і румунів Закарпаття. Саме Лемківщина зазнавала найбільших культурних впливів з боку етнічних поляків та словаків, що виявлялось у формі одягу, способах його оздоблення. Зі свого боку, лемки мали чималий вплив на забарвлення, способи носіння одягу у сусідніх етнічних культурах.

Отже, незважаючи на певні запозичення елементів одягу від сусідніх європейських народів, в цілому український традиційний костюм характеризується виразною етнічністю і оригінальними елементами, які не можна зустріти у жодному іншому національному костюмі. Можна стверджувати, що відбувається не пряме запозичення, а творче осмислення культурних надбань сусідніх етносів, а процес формування традиційного народного костюма $\epsilon$ віддзеркаленням етнічної самоідентифікації. Але саме визначення ступеня унікальності і запозичень елементів етнічної культури дає можливість говорити про особливості історичного розвитку європейських народів, їхню етнічну спільність. Цей напрям дослідження тільки починає розвиватись, що робить тему дослідження надзвичай актуальною і має неабиякий науковий і практичний потенціал.

\footnotetext{
Abstract

The article considers the influence of the regional factor on the formation of a traditional costume as a cultural value community of the ethnic history of European peoples.

Analysis of the researches of the scientific work of the outlined problem in particular the works of O. Kosmin, K. Mateyko, T. Nikolayeva, T. Kara-Vasil'eva, G. Stelmashchuk, V. Kotsana, S. Kryvopustova and others gave an opportunity to define and generalize the ethnic interactions of European peoples, the processes of intercultural communication on the formation of a national costume. The main attention is on the identification of distinctive features and ethnic borrowing in the process of forming and development of folk clothing ethnic groups of Ukrainians in Transcarpathia. In the course of the study, it was found that the similarity of traditional attire of Ukrainians with neighboring ethnic groups is conditioned by common climatic conditions, geographical location, terrain and historical features of development.

The presence of a large number of common varieties of clothing elements, ornamental motifs and techniques of its decoration has become a common element in the development of traditional culture of the ethnic border. Ethnohistorical and economic development of the Ukrainians of Transcarpathia was reflected, firstly, on the local features of the clothing complex, in particular the ways of arrangement, coloring, techniques in embroidery, ornamental motifs. The analysis of the motifs of
} 
ornamentation, composition techniques, arrangement of the decor, functional designation of the elements of folk costume are closely related and interdependent, which allowed to find out the main factors that are directly related to the local peculiarities of the Ukrainian people of Transcarpathia.

Key words: Carpathian Ukraine, ethnocentrism, ethnographic group, traditional culture, folk costumes.

\section{ДЖЕРЕЛА ТА ЛІТЕРАТУРА}

1. Білан М. С., Стельмащук Г. Г. Український стрій. Київ: Апріорі, 2011. 312 с.

2. Васіна 3. О. Український літопис вбрання. Т. 2. XIII - початок XX ст.: Науково-художні реконструкції. Київ: Мистецтво, 2006. 448 с.

3. Етнографічний образ сучасної України. Корпус експедиційних фольклорноетнографічних матеріалів. Т. 10. Традиційне і повсякденне та обрядове вбрання / [голов. ред. Г. Скрипник]; НАН України; ІМФЕ ім. М. Т. Рильського. Київ, 2018. 640 c. URL: http://www.etnolog.org.ua/pdf/stories/spadshchyna/2018/ odyag.pdf

4. Зеленчук В. С. Костюм румынского населения Закарпатской области УССР. Карпатский сборник. Москва: Наука, 1976. С. 69-78.

5. Іваниш А. Іноетнічні запозичення та їх впливи на формування традиційного народного костюму Закарпаття 20-40-х рр. ХХ ст. Вісник Львівської національної академії мистецтв. Вип. 35. С. 309-320.

6. Косміна О. Ю. Традиційне вбрання українців. Київ: Балтія Друк, 2008. Т. І: Лісостеп та степ. 2008. 160 с.

7. Коцан В. В. Традиційний народний одяг гуцулів Рахівщини: XIX - перша половина XX ст. Ужгород: Видавництво Олександри Гаркуші, 2012. 164 с.: іл.

8. Коцан В. Традиційний народний одяг як прояв ідентичності етнографічних груп українців Закарпаття (XIX - першої половини XX ст.) Народознавчі зошити. 2014. № 1 (115), С. 80-97.

9. Мамуня В. М. Українські народні сорочки в колекції Державного Історичного музею Української РCP. Київ: Мистецтво, 1970. 35 с. URL: http://www.academia.edu/29259800/Каталог_Українські_жіночі_народні_сорочки_в_колекції державного_історичного_музею_Української_РСР_1970_

10. Матейко К. І., Полянська О. В.Одяг. Гуцульщина: історико-етнографічне дослідження. Київ: Думка, 1987. С. 189-203. URL: http://www.twirpx.com./ file/1668326/

11. Матюхіна О. А. Національний стиль в одязі як вираз національної самосвідомості. Рідна Мода. Традичійний і сучасний украӥнський одяг для молоді та панства. 2009, 18 січня. URL: http://www.ridnamoda.com.ua/?p=598

12. Ніколаєва Т. А. Історія українського костюма. Київ: Либідь, 1996. 171 с. 
13. Ніколаєва Т. О., Кара-Васильєва Т. В. Особливості народного вбрання та вишивка Українського Прикарпаття. Народна творчість та етнографія. 1988. № 3. С. 67-73.

14. Свйонтек I. Вишивка гуцульських сорочок XIX-XX століть. Народний костюм як виразник національної ідентичності: Збірник наукових праць за ред. д-ра мистецтвознавства М. Селівачова. Київ: ТОВ «ХІК», 2008. 310 с.

\section{References}

1. Bilan M. S., Stelmashchuk H. H. (2011). Ukraïnskiy striy [Ukrainian clothing]. Kyiv: Apriori.

2. Vasina Z. O. (2006). Ukrainskyi litopys vbrannia. T. 2. XIII - pochatok XX st.: Naukovo-khudozhni rekonstruktsii [Ukrainian Chronicle of Dress]. Kyiv: Mystetstvo.

3. Etnohrafichnyy obraz suchasnoyi Ukrayiny. (2008). Korpus ekspedytsiynykh fol'klorno-etnohrafichnykh materialiv. T. 10. Tradytsiyne i povsyakdenne ta obryadove vbrannya [Ethnographic image of modern Ukraine. The body of expeditional folklore and ethnographic materials. T. 10. Traditional and everyday and ritual clothing] / [holov. red. H. Skrypnyk]; NAN Ukrayiny; IMFE im. M. T. Ryl's'koho. Kyyiv. URL: http://www.etnolog.org.ua/pdf/stories/spadshchyna/2018/odyag.pdf

4. Zelenchuk V. S. (1976). Kostyum rumynskogo naselenyya Zakarpatskoj oblasty` USSR [Costume of the Romanian population of the Transcarpathian region of the USSR]. Karpatskyj sbornyk. Moskva: Nauka.

5. Ivanysh A. (2018). Inoetnichni zapozychennya ta yikh vplyvy na formuvannya tradytsiynoho narodnoho kostyumu Zakarpattya 20-40-kh rr. XX st. [Interethnic borrowings and their influence on the formation of the traditional national costume of Transcarpathia 20-40s of the twentieth century]. Visnyk L'vivs'koyi natsional'noyi akademiyi mystetstv. Vyp. 35.

6. Kosmina O. Yu. (2008). Tradycijne vbrannya ukrayinciv [Traditional attire of Ukrainians]. Kyiv: Baltiya Druk, 2008. T. I: Lisostep ta step.

7. Kotsan V. V. (2012). Tradytsiinyi narodnyi odiah hutsuliv Rakhivshchyny: XIX persha polovyna XX st. [Traditional folk costumes of Hutsuls of Rakhiv: XIXfirst half of XX century]. Uzhhorod: Vydavnytstvo Oleksandry Harkushi.

8. Kotsan V. (2014). Tradytsiinyi narodnyi odiah yak proiav identychnosti etnohrafichnykh hrup ukraintsiv Zakarpattia (XIX - pershoi polovyny XX st.). [Traditional folk costumes as a manifestation of the identity of ethnographic groups of Ukrainians of Transcarpathia (XIX - first half of the XX century)]. Narodoznavchi zoshyty. № 1 (115). 
9. Mamunya V. M. (1970). Ukrayins'ki narodni sorochky v kolektsiyi Derzhavnoho Istorychnoho muzeyu Ukrayins'koyi RSR [Ukrainian folk shirts in the collection of the State Historical Museum of the Ukrainian SSR]. Kyiv: Mystetstvo. URL: http://www.academia.edu/29259800/Каталог_Українські_жіночі_народні_coрочки_в_колекції_державного_історичного_музею_Української_РСР_1970_

10. Matejko K. I., Polyans`ka O. V. (1987). Odyag. Guczulshhyna: istoryko-etnografichne doslidzhennya [Hutsul region: historical and ethnographic study]. Kyyiv: Dumka. URL: http://www.twirpx.com./file/1668326/

11. Matyukhina O. A. (2009). Natsional'nyy styl' v odyazi yak vyraz natsional'noyi samosvidomosti [National style in clothing as an expression of national identity]. Ridna Moda. Tradytsiynyy i suchasnyy ukrayins'kyy odyah dlya molodi ta panstva. URL: http://www.ridnamoda.com.ua/?p=598

12. Nikolaieva T. A. (1996). Istoriia ukrainskoho kostiuma [History of the Ukrainian costume]. Kyiv: Lybid.

13. Nikolayeva T. O., Kara-Vasyl'yeva T. V. (1988). Osoblyvosti narodnoho vbrannya ta vyshyvka Ukrayins'koho Prykarpattya [Features of the national dress and embroidery of the Ukrainian Carpathians]. Narodna tvorchist' ta etnohrafiya. № 3.

14. Svyontek I. (2008). Vyshyvka hutsul's'kykh sorochok KHIKH-KHKH stolit' [Embroidery of Hutsul shirts XIX-XX centuries]. Narodnyy kostyum yak vyraznyk natsional'noyi identychnosti: Zbirnyk naukovykh prats' za red. d-ra mystetstvoznavstva M. Selivachova. Kyyiv: TOV «KHIK». 